\title{
Beliefs and practices of culture care in colombian Wayúu pregnant women
}

\author{
Creencias y prácticas de cuidado genérico en gestantes Wayúu colombianas \\ Crenças e práticas genéricas de cuidado de gestantes de Wayuu Colombiano
}

Ariadna María Angarita-Navarro*
Martha Patricia Bejarano-Beltrán

\section{Autor de correspondencia}

* Enfermera. Especialista en Salud Ocupacional. Maestría en Enfermería. Docente de Planta. Fundación Universitaria del Área Andina. E-mail: amangaritan@unal.edu. co ORCID: (D) https://orcid.org/0000-00016717-4871 Bogotá. Colombia.

** Enfermera. Especialista en Materno-perinatal. Maestría en Enfermería. Profesora Asistente, Facultad de Enfermería, Universidad Nacional de Colombia. E-mail: mpbejaranob@unal.edu.co Orcid: iD https://orcid. org/0000-0002-0543-1411 Bogotá, Colombia.
Este es un artículo bajo la licencia CC BY

(https://creativecommons.org/ licenses/by/4.0/) (c) ()

\begin{abstract}
Objective: Understand the beliefs and care practices of the expectant mothers of the Wayuu indigenous community in the rancherias Sapalou and Sutalu, La Guajira. Methodology: Qualitative study with an ethnographic focus, which was performed on eleven expectant mothers of the mentioned indigenous community. The information was obtained through participative observation and a semi-structured interview. For the analysis of the data, the analysis guide of four tenets by Leininger was used. Results: The Wayuu expectant mothers described the practices of prenatal care inherited from their culture. During pregnancy, Wayuu mothers are not allowed to eat some foods such as shrimp, crab, rabbit or turtle, to prevent complications at birth and in the child to be born. They do not have contact with people that have committed murder, manipulated corpses or have assisted to funerals, since according to their beliefs this can cause bleeding at birth. The midwife becomes a significant member of the community during the pregnancy and labor process. Conclusions: It is imperative that nursing understands the cultural traits of the indigenous communities to bring holistic and quality nursing. Also, it is indispensable to continue with studies that explore the beliefs and practices of care during labor and postpartum of this populations.
\end{abstract}

Keywords: nursing care, pregnancy, cultural characteristics, transcultural nursing.

\section{Resumen}

Objetivo: Conocer las creencias y prácticas de cuidado de las gestantes de la comunidad indígena wayuu en las rancherías de Sapalou y Sutalu, La Guajira. Metodología: Estudio cualitativo con enfoque etnográfico, el cual se llevó a cabo con once gestantes de dicha comunidad indígena. La información se obtuvo mediante la observación participativa y una entrevista semiestructurada. Para el análisis de los datos, se utilizó 
la guía de análisis de cuatro fases propuesta por Leininger. Resultados: Las gestantes wayuu describieron las prácticas de cuidado prenatal heredadas por su cultura. Durante la gestación, las wayuu se cohíben de comer algunos alimentos, como camarón, cangrejo, conejo o tortuga, para evitar complicaciones en el parto y en el hijo por nacer. No tienen contacto con personas que hayan cometido homicidio, manipulado cadáveres o asistido a funerales, pues según sus creencias esto puede generar sangrados durante el parto. La partera se convierte en un miembro significativo en la comunidad durante el proceso de gestación, trabajo de parto y parto de las gestantes. Conclusiones: Es imperativo que la enfermería conozca los rasgos culturales de las comunidades indígenas para brindar cuidados holísticos y de calidad. Así mismo, es indispensable continuar con estudios que indaguen las creencias y prácticas de cuidado durante el parto y el puerperio de este tipo de población.

Palabras clave: Atención de enfermería, gestación, características culturales, enfermería transcultural.

\section{Resumo}

Objetivo: Conhecer as crenças e práticas de cuidado das mulheres grávidas da comunidade indígena Wayuu ou uaiús em ranchos de Sapalou e Sutalu, Estado de "La Guajira", na Colômbia. Metodologia: Estudo qualitativo com uma abordagem etnográfica, o qual foi realizado com onze mulheres grávidas da referida comunidade indígena. A informação se obteve através da observação participativa e uma entrevista semiestruturada. Para a análise dos dados, utilizou-se a guia da análise de quatro fases proposta por Leininger. Resultados: As mulheres grávidas Wayuu descreveram as práticas de cuidado pré-natal herdadas por sua cultura. Durante a gestação, as wayuu são inibidas de comer alguns alimentos como: camarão, caranguejo, coelho ou tartaruga, para evitar complicações no parto e no filho que está por nascer. Não têm contato com pessoas que tenham cometido homicídio, manipulado cadáveres ou ter participado de funerais, pois segundo suas crenças isto pode gerar sangramentos durante o parto. A parteira se converte num membro significativo na comunidade durante o processo de gestação, trabalho de parto e parto das grávidas. Conclusões: é imperativo que a enfermagem conheça as características culturais das comunidades indígenas para fornecer cuidados holísticos e de qualidade. Assim mesmo, é indispensável continuar com estudos que indaguem as crenças e práticas de cuidado durante o parto e o puerpério deste tipo de população.

Palavras-chave: Atendimento de enfermagem, características culturais, enfermagem transcultural, gestação.

\section{Introduction}

Colombia, as well as other countries has the drive of pursuing the Sustainable Development Goals. The third goal proposes "By 2030, reduce the global maternal mortality ratio to less than 70 per 100.000 live births" (1). However, it is important to note that although Colombia has improved the perinatal and maternal healthcare, there are still social, political, economical and demographic barriers that limit the accomplishment of decreasing maternal mortality cases, especially in isolated and vulnerable populations (2).

Furthermore, according to the Colombian National Institute of Health, since the beginning of 2017, the National System of Public Health Surveillance (SIVIGILA) has notified 451 cases of maternal mortality, from which 314 were early deaths and 104 were late maternal deaths; that is to say, up to one year after giving birth (3). From the total maternal deaths reported, the department of La Guajira represents 183 cases out of 100000 live births, which constitutes an elevated number on a national level, since it surpasses the preliminary ratio of 47 out of every 100000 live births (3). Although the data of the reported cases of maternal deaths are elevated, we must consider the possible existence of underreports. Pregnant Wayuu women do not generally attend healthcare institutions when giving birth, they are attended at home by traditional midwifes; this could be a reason for a greater number of maternal deaths. A document made by the Inter-American Commission on Human Rights indicates that "the procuracy of the Guajira Government reports an existent preoccupation for the underreport of maternal deaths in the department of La Guajira. In particular, it is informed that almost all the deaths were reported by the health System, but apparently 
ISSN-PRINT

1794-9831

E-ISSN 2322-7028

Vol. 16 No. 1

Ene - Abr 2019

Cúcuta, Colombia from the dispersed rural population, especially the indigenous, the maternal deaths are not reported to the Health System and are classified as underreports" (4).

Likewise, the department of La Guajira has a great number of disperse population in different rancherias of indigenous communities, a factor that complicates the care of pregnant women that belong to these communities (5). One of these communities is the Wayuu, which counts with a cultural wealth that is identified by the rest of Colombians; however, their customs and beliefs become barriers for those who do not know them. This situation, makes necessary for all the health personnel, including nurses, to recognize, respect and bring the appropriate care of pregnant women by considering the cultural aspects of this population.

On the other hand, to accomplish the objective of the research, the theory of culture care diversity and universality by Leininger was used. The study parts from the need of recognizing the holistic nursing of Colombian women as a contribution to nursing knowledge. Regarding the cultural focus, Leininger indicates that these types of studies are necessary, since care is inherent to culture. Also, pregnancy involves care practices and beliefs that are learned from generation to generation, which is considered of great cultural importance (6).

In her theory, Leininger defines relevant concepts. One of these is culture care, indicating that: "It is referred as the knowledge and the practices learned and transmitted by seculars, indigenous, natives or locals (emic) to provide help, support, empowerment, and facilitation for others with evident or anticipated health needs to improve their well-being, help in their death or other human conditions" (7). One of the objectives of this research is to understand the culture care, or care learned and transmitted within the indigenous Wayuu community during pregnancy.

Another concept defined by Leininger was related to professional care: "Care in professional nursing (ethic), knowledge and practices generally obtained through educational institutions (non-conventional). Nurses and other people are taught to provide acts of support, empowerment, or facilitation towards another individual or group with the purpose of improving their well-being, prevent diseases, or help in their death or other human conditions" (7). From this perspective, professional care is important to mention, in virtue of nursing explaining it based on scientific knowledge. This practice is learned by students in educational institutions, where knowledge must be transmitted in a clear and easy way to the general population, including indigenous communities. Professional care must therefore be learned and replicated by nursing students in people that have not had education on this discipline and is necessary to improve adequate selfcare, as well as to preserve health and prevent disease.

From a social perspective, nursing must appropriate its role and apply it in the most vulnerable groups as the cases of Manaure and Uribia, regions where the Wayuu are located, and transcultural care can be provided to them. Therefore, nursing must not ignore the importance of observing and recognizing the Wayuu culture (during pregnancy) to provide the best care to one of the populations that demands greater support and care.

Regarding the theoretical aspect, it is necessary to relate the study phenomenon with a proper nursing theory to give scientific support, this study worked with the culture care theory of diversity and universality. It tries to deepen further on opinions, dogmas, ideologies and behaviors of the pregnant Wayyu, unknown by most of the Colombian population specifically by Nursing.

Similarly, regarding the disciplinary aspect, this research has the focus of recognizing cultural aspects related to pregnancy care of women that belong to thee Wayuu community, allowing nursing to empower better transcultural care with this contribution.

\section{General Objective}

Describe the beliefs and care practices of pregnant women belonging to the indigenous Wayuu community in the Sapalou and Sutalu rancherias located in the municipality of Uribia, Guajira.

\section{Materials and Methods}

This is a qualitative study of ethnographic type, based on ethnonursing research method proposed by Leininger to identify the beliefs and practices associated to the care of pregnant women from the Wayuu community in the Sapalou and Sutalu rancherias from the Guajira department (7). The sunrise model from 
Leininger was used as a guide to determine the beliefs and care practices of pregnant Wayuu women (8). The analysis of the information was performed applying the four tenets for the analysis of qualitative data established by Leininger (9).

The research was performed with the participation of eleven indigenous pregnant women, who accepted and authorized giving the necessary information. They were informed about the objectives of the research, the conditions such as no economic remuneration for participating, no harm of any kind, and that the information provided would be used with confidentiality. Previous to this, the leaders of the two rancherias helped the researcher to locate the possible participants (considering the criteria of inclusion and exclusion). Initially there were 12 participants, they were informed about the objectives of the study through translators; one of the pregnant women decides not to participate because there is no economic remuneration, the study was only able to collect information from 11 participants. As inclusion criteria the following were considered: the participation of pregnant Wayuu women in any trimester of pregnancy, that the participants were in condition to answer the interview, spoke their native language wayuunaiki or Spanish, and belonged to the rancherias Sapalou and Sutalu. As exclusion criteria the following were considered: women that were in labor process, postpartum or pregnant Wayuu women from different rancherias or the urban area.

For the recollection of data, the participant observation was used with the purpose of describing daily situations for pregnant women in the Wayuu community. Also, a daily registry was made to record information and a semi-structured interview was given to each participant, until obtaining enough information.

\section{Procedure}

In order to communicate with the pregnant women, two translators participated: one for each rancheria -women dedicated to teaching in primary school. Similarly, it was necessary to communicate with the leader or authority of each of the rancherias to allow the study to be performed in their communities.

According to the four tenets which make part of the ethnonursing guide of data analysis proposed by Leininger (9), this study was developed as follows: in the first tenet, the data was recollected and the interviews were transcribed and interpreted, these were codified using the letter "P" to refer to the participant, the letter "E" to indicate interviews, and a number to make reference both to each participant and the number of interviews (e.g.: P1E1= participant one, interview one); the second tenet, the descriptors and categories were determined; the third tenet, the recurrent patterns were identified: and in the fourth tenet, the findings were established and all the information was interpreted.

\section{Methodological Rigor}

Credibility: for the information collected to be credible it was necessary to work with empathy from the researcher toward the participants and the community; also, trust was established between the participants to provide accurate and consistent information (8).

Corroboration: when collecting information through interviews, it was observed that the answers and comments of the participants used unknown terms to the researcher, making necessary to reconfirm the information given to determine that the communicated was in fact what the participants wanted to express (8).

Meaning in context: the information provided by the pregnant Wayuu was influenced by their own specific context from the rancherias Sapalou and Sutalu, as well as their beliefs, symbols, rituals and else (8).

Recurring patterns: these were obtained through the information and observation where care practices described by pregnant Wayuu are repeated (8).

Saturation: it was met when the participants gave the enough and repetitive information and consequently there was no additional information (8).

Transferability: currently there is no transferability; this study will be available to any researcher who wants to use it in any region or department in Colombia (8).

The study obtained the approval from the Ethics Committee of the Nursing Faculty of the National University of Colombia on February 9th, 2017 with endorsement 02-17. The city hall of the Uribia municipality emitted the respective authorization to obtain the information and work with the participants of the rancherias Sapalou and Sutalu, whose leaders consented the entry to the communities through written permissions. The pregnant women authorized and 
ISSN-PRINT

1794-9831

E-ISSN 2322-7028

Vol. 16 No. 1

Ene - Abr 2019

Cúcuta, Colombia confirmed their participation by signing an informed consent - only one of the 11 participants signed with her finger print since she did not know how to sign. The study was based on the ethical principles of charity, autonomy, fidelity, veracity and confidentiality.

\section{Results}

The present study performed on the rancherias of Sapalou and Sutalu, Guajira, allowed the understanding of beliefs and cultural practices related to culture care during pregnancy of Wayuu women. The most relevant care practiced by Wayuu women during this life cycle will be described next.

\section{Beliefs and care related to "belly"}

\section{Sleep Face-up}

Among cultural care associated to the belly, pregnant Wayuu manifested that it is important to sleep face-up from the moment they know about their pregnancy up to the first three months - during the embryonic period. The participants justified this behavior based on the belief that if they sleep on their sides or facedown, the baby will stay on the same position during the whole pregnancy and will difficult giving birth:

"The only position, is to sleep face-up from the moment the woman knows about the pregnancy, she has to be very careful on how she sleeps, because if she sleeps face-down, the baby will stay on the position the mother sleeps, the baby tends to stay on the side the mother sleeps on" (P1E1),

\section{Rubbing the belly}

Pregnant women from the indigenous Wayuu community prefer to be attended by midwifes, who in these cases represents a determinant role in the community, since according to the participants the midwife "is not an ordinary person", she is born with the gift of taking care of pregnancies. The midwife "checks the belly" and defines if the child to be born is in an adequate position. Otherwise, the midwife will massage the belly with an alcohol (denominated chirrinchi) until the fetus is in an adequate position and ensure labor will not take much time. This process needs various encounters: if it is necessary, the midwife will rub the belly once a month until labor, and perform the respective care:

"What I know about midwifes is that they "fix" bellies of pregnant women when the baby is in a bad position. They take the midwife there or search for her and make an examination like twice and that's all. There are midwifes that know if the creature is crossed, but the midwife can "fix" that's what I know about it" (P9E1).

\section{Food care}

\section{Not eating too much because the child will get fat}

Regarding food consumption during pregnancy, the participants affirmed that it is preferable to note at much, especially when the childbirth is close, since it is believed that the baby will be too big at birth and labor will be difficult:

"Not eating too many fats, the child will come out with a big head, but things like that, or if you have cravings" (P8E1).

"Also, when a woman eats too much, she must control her food intake. She cannot eat in abundance because the child will come out too fat" (P1E1).

\section{Not eating catfish}

Some of the pregnant women that were interviewed pointed out that their customs did not allow them to eat catfish because the labor time might become longer. They associate the behavior of this fish species and their movements with the labor process since catfish tend to give birth from their mouth. According to the indigenous perspective, during birth, the baby could advance to the birth canal and return, implicating a longer labor process.

"They have also told me that there is a fish we cannot eat: catfish, because the baby will come up. If you eat that at the beginning of the pregnancy, then at birth the pain will go up instead of down. It is as if the child wants to go up instead of down: that is because catfish give birth from their mouth. That is what fishers say" (P3E1).

Avoid the parrot to take the food from the pregnant.

The participants manifested that they are forbidden from eating foods that were tasted by a parrot, this can cause green bowel movement on the newborn baby:

"Animals can also interfere in the pregnancy. If there is a parrot at home, they have to be careful with the food, because the parrot is an 
animal that walks around, and it is possible for the parrot to eat your food, if you eat the food after the parrot, the newborn will have difficulties. The baby will have diarrhea and will be sick. They say that when they notice the sickness is because of one of these animals, the green color the babies defecate, as much medicine as they give them will not help until they give them a medicine called wito or they give the parrot food from the baby and then feed the baby" (P4E1).

\section{Not eating snail or shrimp}

The snail and the shrimp are marine animals that have a coiled position, reason why some pregnant women who were interviewed expressed that their community warned them to note at snails or shrimp because the child could take the same position of these animals: coiled. This could be problem at childbirth because the position would make labor more difficult:

"It makes childbirth more difficult, you cannot give birth quickly, it takes longer. They say that shrimp is an animal that shrinks. Then the child moves, and makes the movement of a shrimp, so the child does not want to come out. They have to find the same shrimp, cook it and you have to drink the water where the shrimp was cooked" (P4E1).

\section{Not eating turtle.}

The participants of this study informed that their families forbid eating turtle, since the Shell is rigid. According to them, when labor comes, the belly hardens and feel a lot of pain:

"[...] because it makes childbirth difficult. You know turtles have a shell, the belly tends to become hard when you are on the labor process" (P7E1).

\section{Care related to daily activities}

\section{Not carrying weight}

The expression carrying weight makes reference to lifting heavy loads, factor related to carrying water that is transported in cans. As it is well known, rancherias in the Guajira do not have potable water, but there are wells, - denominated hawey -where rain water is collected. The activity of collecting water for family consumption is generally assumed by women and children. The hawey are distant from homes, reason why pregnant women would force themselves too much for such activity:

"We cannot go up to the hawey because we could fall or slip. We cannot lift weight. [...] that is when you go to the hawey with cans to bring water. You have to ask for help to put the cans on the donkey. We cannot grab it because you have to push it, how are you going to hold it with a belly" (P8E1).

\section{Shower early to prevent colds.}

Some of the pregnant women from the indigenous Wayuu community expressed that they had to prevent "catching" a cold during pregnancy. With the word "cold" they mean nothing can warm them up; from there is the belief that this can cause the child to be born also feeling cold:

"Colds are bad because I get headaches, it can even cause me to vomit. Then, the fear is the baby to get the cold. [...] Yes, the baby can get it, most of the times when they do not have care for the babies, they are born crying, like they have a cramp, like something hurts them. If you take them to the doctor, they say its normal, but the baby can be affected by this. The cares a pregnant woman must have are many" (P6E1).

\section{Be in constant activity}

The participants of this study affirmed that "pregnancy is not a disease". In the Wayuu culture, a pregnant woman must be in constant activity and preferably, not sleep during the day.

"[...] because I do not like to feel useless, because pregnancy is not a disease" (P8E1).

"Walking is good. They always tell us to walk, to not be lazy, sitting, that we have to be active: I do easy tasks, sometimes I sweep...; I don't stay still all the time" (P4E1).

\section{Drinking sangre de mono to be healthy and strong}

The consumption of sangre mono (medicinal plant) is a practice performed to increase vitality and maintain an appropriate weight. During pregnancy, it is believed that this plant provides strength at birth:

Cúcuta, Colombia
E-ISSN 2322-7028

Vol. 16 No. 1

Ene - Abr 2019 
ISSN-PRINT

1794-9831

E-ISSN 2322-7028

Vol. 16 No. 1

Ene - Abr 2019

Cúcuta, Colombia is lost, then you will not look weak after labor and you will have strength" (P6E1).

Not offering food to those who have had contact with dead bodies or have committed homicide.

Pregnant women of the Wayuu community manifest that it is a custom not offering food to people that have manipulated dead human bodies. If someone is in charge of lifting and washing a corpse or if they have committed a murder, the person is not received as a dinner guest in the home of a pregnant woman, because, according to them, bleeding can occur, and this can complicate giving birth:

"My mom told me to be careful of receiving or giving food to people that have touched remains or have washed dead bodies [...]. When a person has killed someone, and the pregnant woman does not know, it can cause a miscarriage; they say it is effective. Those are ways to take care: if you do not know if a person has killed someone, you do not go offer anything to them" (P3E1).

\section{Not looking at dead bodies.}

Apart from the previous practice, the participants manifested they should not go close to the dead body in the funeral ceremony or at the burial, they believe they could bleed, causing a miscarriage.

"One of the precautions you must consider is not going close to funerals. When they are preparing the dead body, you must not go close, you have to isolate yourself, you cannot be at funerals like that, of a dead person that was killed violently, by shots, or by accident, because emotionally you feel like in shock, you take that impression, transmit it to the baby and you start to bleed and suffer a miscarriage" (P8E1).

\section{Taking alepo to ease giving birth.}

Alepo is a medicinal plant used to stimulate uterine contractions. When a Wayuu woman starts to feel labor pain and contractions, family members search for a midwife, who prepares a drink with this plant:

"It is a medicinal plant, they take it, crush it, grind it and shape it like a roll; they shred it and that is what I have to drink. You drink it when you feel labor pain, so you can give birth quickly" (P2E1).

\section{Discussion}

The belief of sleeping face-up for pregnant Wayuu women is not evidenced on other indigenous communities, according to literature; but in a research performed in Mexico by Lina Berrio, cultural practices were defined, and these are performed by pregnant women from various indigenous communities, among them the $\mathrm{Na}$ Savi and the Nancue Nomda. Regarding daily life practices, pregnant women that belong to these communities avoid sleeping during the day to prevent the baby to stick, which would difficult giving birth (10).

On the other hand, while the indigenous Wayuu community is careful with the sleeping position during pregnancy, Mexican communities are precautious about sleeping during the day; in both circumstances the objective is prevent birth complications. It must be noted that, pregnant Wayuu women only perform this practice during the first trimester, related to the embryonic period; in the first trimester of pregnancy organogenesis occurs, a vulnerable period for the embryo since its systems and organs are formed: "the three germ layers, ectoderm, endoderm, and mesoderm, give origin to various specific tissues and organs" (11). Concerning the perception of the participants, while it is true that the embryonic period of the pregnant woman must be monitored because the embryo is susceptible of suffering malformations due to exposure to chemical substances or medication (12), science evidences that the sleep position does not determine the position of the baby when the mother is giving birth.

Also, the practice of rubbing the belly (13) is very common in various indigenous communities. In a community from Yucatan-Mexico, the result of an article of anthropologic research performed on this population pointed that: "at the beginning of the third month, rubbing or yeet' is of vital importance for the well-being of the pregnant mother. An expert midwife is able to accommodate the child through massages, bring the baby up when they are positioned too low, causing pressure on the bladder of the mother or difficulty when walking" (14). However, this practice is performed not only by indigenous communities, but also by midwifes of the Pacific region of Colombia: "rubbing the belly" becomes a proper activity of the midwifes in the north of Colombia. Regarding this, a midwife that belongs to the United Midwife Association of the Pacific (ASOPARUPA) notes that "as of the seventh month, we start to prepare the mother and the 
baby for the birth through massages, by rubbing the belly we accommodate the baby, in a way that the head is facing down to avoid a cesarean delivery" (15).

Pregnant Wayuu women that participated on this research referred that generally they try not to eat excessively during pregnancy, this practice is used in many communities where a traditional midwife still exists, this is a way of reducing dystocia caused by macrosomia; a fetal weight greater than 4000 grams can cause complications at birth, it does not allow the baby to fit or come out of the vaginal canal. Dystocia can cause prolonged labor, causing hypoxia and even death to the baby (16). Similarly, a regular care practice in the indigenous communities is to regulate the food intake of pregnant women to prevent complications at birth due to macrosomia. This is the reason why, the pregnant women of the awajun and wampins of the peruvian amazon do not eat chonta, because the baby could become macrocephalic; they do not eat ojé either, since its believed it can make the baby too big and could cause complications at birth (17).

There are some cultural beliefs in the indigenous Wayuu community, possibly based on myths, such as not eating catfish to prevent complications when giving birth, it can be considered a belief influenced by the fishermen of the region. Wayuu women relate it to a complication at birth, believing that the fetus does not come down when they eat catfish, since this fish gives birth from their mouth. To find some type of relationship, a research about reproduction of catfish was made, consulting the Office of Agricultural Development, explaining the reproduction of this fish. The male builds a nest in the sand for the female to lay the eggs; then the fish nest the eggs by flapping them for a period from five to ten days (18). However, the fish are not born in the mouth of the fish, as believed by the pregnant Wayuu women. Therefore, the aforementioned indicates that this cultural belief, transmitted from generation to generation, is revealed as a myth.

Another care practice based on cultural beliefs is, not eating food previously manipulated by a parrot, if this were to happen, the newborn bowel movement would look greenish; this coloration in newborn babies is normal: it is denominated meconium. The texture of the feces if viscous, sticky, and the color is dark green. It is composed of water, lipids, proteins, sterols, cholesterols precursors, fatty acids, epithelial cells, bile, and intestinal secretions (19). Although it is possible for pregnant Wayuu women to associate the feces of the baby with the feces of the parrot because of its green appearance, meconium on the newborn is a product of the waste and does not imply abnormalities in their health.

Like in other cultures, the need to check the belly is necessary (20), or rubbing the belly as referenced by the Wayuu to know the position of the baby. The ideal is for the baby to be in a cephalic position (21). Similarly, the participants of the research suggested that eating shrimp would prevent the baby to be in this position and birth could be prolonged. However, a study performed on the awajun and the wampis reported that eating shrimp made part of a healthy nutrition for the pregnant women and did not cause complications (17). This evidences that this is a precaution based on cultural beliefs.

Something similar occurs related to eating turtle, considering this causes the belly to harden, uterine pain and bleeding. However, these symptoms tend to occur when the mother presents uterine tachysystole, making contractions more painful and occur more often. The causes can be hyperdynamic uterine contractions, uncoordinated contractions, uterine atony caused by a placental abruption (22). Uterine tachysystole causes intrauterine hypoxia, not allowing oxygen to get to the baby.

On the other hand, for care relating to daily activities of the pregnant Wayuu, they indicate that they should not lift heavy weight; it has been demonstrated that there is a higher incidence of premature births caused by lifting heavy objects. Although a weight limit for pregnant women does not exist, its recommended not to lift heavy objects (23). According to our results in a study performed on the Mexican p'urhépecha community, the interviewed indigenous affirmed that during pregnancy they should not carry water, because the child might be born with bruises, which is normally associated with Mongolian spots babies are born with (24).

Another important aspect to consider regarding care of pregnant Wayuus is getting a cold; for years indigenous and afro Colombian communities have believed that an equilibrium between cold and heat must exist. The cold received can be considered as impure, as a disease (25). Preventing cold for the interviewed Wayuu women is similar to the pregnant women from the study performed on the awajun and the wampis, who avoid getting cold or receiving air because they 
ISSN-PRINT

1794-9831

E-ISSN 2322-7028

Vol. 16 No. 1

Ene - Abr 2019

Cúcuta, Colombia believe giving birth will take longer or cause hemorrhages. In the case of a cold, midwifes provide basil infusions to improve the health of the woman (17).

According to this research, for Wayuu women, the concept of pregnancy is considered a disease only for tradition, reason why performing any physical activity is considered dangerous (26). As well as for indigenous communities' pregnancy can be considered as a normal process in the life of a woman, in a study performed by the ECLAC-United Nations, in Chile its claimed that, "pregnancy is not necessarily considered a danger, but rather a desired and even sought state" (27). Pregnant Wayuu women, according to this statement claim they perform their daily activities without inconveniences; if the exercise is moderate, there is no risk of miscarriage, it will not stimulate uterine contractions and will avoid premature births. This way, Wayuu women will carry out a healthy care practice during their pregnancy, considering physical activity brings benefits (28).

Similarly, a study performed on the indigenous Zenú communities to understand their practices on pregnant women indicates that women recognize the importance of an adequate diet during pregnancy to have strength at birth. For them, their diet must be based on fruits and vegetables, such as beetroot and carrot juice (29). The results of the study mentioned coincide with the present study regarding practices of pregnant Wayuu women since they drink sangre de mono to feel strength at birth. Also, it is confirmed that pregnant women drink pariise to gain strength after giving birth and also after the first menstruation of the Wayuu girl, when they become women (30).

There are many spiritual beliefs in the indigenous Wayuu communities, and they protect themselves from this perspective during pregnancy. In the bibliographic reviews, there was no evidence of other cultures practicing these beliefs (offering food or beverages to someone that has killed a person, visiting funerals, among others), but there is a common relation with spirits. For example: a study performed on the indigenous q'eachi community in Guatemala indicates that pregnant women believe that they should not be in contact with spirits because they can produce fear, and cause stomachache. They pray, light incense and are advised to stay in to prevent being touched by spirits (31).

Lastly, midwifes from the Pacific region of Colombia, as well as midwifes from the Wayuu community must prepare infusions for the pregnant; similarly, they prepare drinks to "ease labor" and beverages with yerba de la virgen and albahaquilla to increase uterine contractions (15); these infusions have the same function as "Alepo", considering them uterotonic plants, used in both communities to help in the labor process.

\section{Conclusions}

- The research provides information which contributes to nurses who take care of pregnant women that belong to the Wayuu community, and for nurses to recognize their culture care based on their cultural beliefs.

- The study allowed identifying beliefs and culture care practices of pregnant women from the Wayuu community that are also performed on other indigenous and afro Colombian communities.

- It is also inferred from this research that there are culture care practices during the pregnancy of Wayuu women related to not eating turtle, shrimp and rabbit to prevent complications during labor, actions that are based on cultural beliefs.

- This research did not perform the culture care negotiation as described by Leininger, but the objective of understanding culture care during pregnancy was met. Also, it is concluded that it is necessary to make research studies about medicinal plants used by the Wayuu community to understand their properties and their benefits during pregnancy. Likewise, it is necessary to research about the nursing performed by midwifes, considering they have an important role in the community, since besides of nursing and attending births in their indigenous communities, they maintain their customs throughout time.

\section{Conflict of interest}

The authors declare not having any conflict of interest 
1. Programa de las Naciones Unidas para el Desarrollo (PNUD) Colombia. Objetivos de Desarrollo Sostenible: Objetivo 3: buena salud [Internet]. Bogotá: 2015 [Consultado 11 nov 2017]. Disponible en: http:/www.co.undp.org/content/colombia/es/home/post-2015/sdg-overview/goal-3.html

2. Ministerio de Salud y Protección Social, Instituto Nacional de Salud, Observatorio Nacional de Salud. Una mirada al ASIS y análisis en profundidad: informe técnico. $7^{a}$ edición. Bogotá: Instituto Nacional de Salud; 2016.

3. Instituto Nacional de Salud. Boletín Epidemiológico Semanal: semana epidemiológica 48. Bogotá: Instituto Nacional de Salud/Dirección de Vigilancia y Análisis del Riesgo en Salud Pública; 2017.

4. Comisión interamericana de derechos humanos. Resolución 3/2017. Ampliación de beneficiarios a favor de las mujeres gestantes y lactantes de la Comunidad Indígena Wayúu en los municipios de Manaure, Riohacha y Uribía respecto de Colombia. 26 de enero de 2017. https:/www.oas.org/es/cidh/ decisiones/pdf/2017/3-17MC51-15-CO.pdf

5. Puerta-Silva C, Dover R. Desarrollo de un modelo de interlocución para el sistema de salud basado en el caso de La Guajira colombiana. Rev Salud Pública [Internet]. 2007 [Consultado 23 de enero de 2017]; 9(3):353-368. Disponible en: http://www.scielo.org.co/pdf/rsap/v9n3/v9n3a04.pdf

6. Muñoz-Enríquez M, Pardo-Torres MP. Significado de las prácticas de cuidado cultural en gestantes adolescentes de Barranquilla (Colombia). Aquichán [Internet]. 2016 [Consultado 23 de enero de 2017]; 16(1):43-51. Disponible en: http://dx.doi.org/10.5294/aqui.2016.16.1.6

7. Wehbe-Alamah HB, McFarland MR. The ethnonursing research method. In: McFarland MR, Leininger's culture care diversity and universality: a worldwide nursing theory. Burlington, Massachusetts: Jones \& Bartlett Learning; 2015. pp. 35-69.

8. Leininger M. Culture care diversity and universality theory and evolution of the ethnonursing method. In: Leininger M, Mcfarland MR. Culture care diversity and universality a Worldwide Nursing Theory. $2^{\text {nd }}$ ed. Massachusetts: Jones and Barlett Publishers; 2006. pp. 1-43.

9. Leininger M. Part I. The theory of culture care and the ethnonursing research method. In: Leininger M, Mcfarland MR. Transcultural nursing: concepts, theories, research, and practice. $3^{\text {rd }}$ ed. New York: McGraw-Hill Education. pp. 71-98.

10. Berrío-Paloma LR. Diversidad de atención durante el embarazo y el parto: reflexiones sobre los saberes locales de mujeres indígenas [Internet]. Universidad Autónoma Metropolitana, unidad Iztapalapa. Disponible en: http://cnegsr.salud.gob.mx/contenidos/descargas/GySenC/Volumen13_3/13_3Art1.pdf

11. Sadler TW. Embriología médica con orientación clínica de Langman. $8^{a}$ ed. Madrid: Editorial Médica Panamericana; 2001.

12. Rodríguez M, Tamayo M, Rivadeneira F. Agentes teratogénicos y teratogenicidad. Colección derecho a vivir en desventaja. Universidad Javeriana Folleto $\mathrm{N}^{\mathrm{o}} 10 \mathrm{http}$ //www.javeriana.edu.co/ documents/5782625/5901279/10+-+Teratogeno.pdf/8d22feb3-096b-4ddf-b31c-94a9bba1357c

13. Quattrocchi P. ¿Qué es la sobada? elementos para conocer y entender una práctica terapéutica en Yucatán. Península [serie en Internet]. 2006 [Consultado: 18 de feb de 2017]; 1(2):113-169. Disponible en: http://www.revistas.unam.mx/index.php/peninsula/article/viewFile/44331/40068

14. Alfaro Abraham AR. Embarazo y posparto en las mujeres mayas. Revista gaceta $\mathrm{N}^{\circ}$ 47. México. 2009

15. Quiñones L, López G, Valencia T, Cuero S, Gómez BC. Plan especial de salvaguardia de los saberes asociados a la partería afro del Pacífico. Buenaventura: Ministerio de Cultura, ASOPARUPA; 2016.

16. Mercado ME. Distocias. En: Parra MO, Ángel E (Eds.). Obstetricia integral siglo XXI. Tomo II. Bogotá: Universidad Nacional de Colombia; 2010.

17. Medina A, Mayca J. Creencias y costumbres relacionadas con el embarazo, parto y puerperio en comunidades nativas Awajun y Wampis. Rev Perú Med Exp Salud Pública [serie en Internet]. 2006 [Con- 
ISSN-PRINT

$1794-9831$

E-ISSN 2322-7028

Vol. 16 No. 1

Ene - Abr 2019

Cúcuta, Colombia sultado: 18 de feb de 2017]; 23(1):22-32. Disponible en: http://www.scielo.org.pe/pdf/rins/v23n1/ a04v23n1.pdf

18. Lara-Rivera AL, Parra-Bracamonte GM, Sifuentes-Rincón AM, Gojón-Báez HH, Rodríguez-González H, Montelongo-Alfaro IO. El bagre de canal (Ictalurus punctatus Rafinesque, 1818): estado actual y problemática en México. Lat Am J Aquat Res [serie en Internet]. 2015 [Consultado: 23 de mar de 2017]; 43(3):424-434. Disponible en: http://dx.doi.org/10.3856/vol43-issue3-fulltext-4

19. López SM, García SP, Velasco MO. Meconio: vehículo de biomarcadores de exposición a sustancias psicoactivas en gestantes. Nova [serie en Internet]. 2007 [Consultado: 23 de mar de 2017]; 5(7):76-83. Disponible en: http://dx.doi.org/10.22490/24629448.377

20. Rivera Solano NI, Yepes Requeme MY. Suárez de la cruz MC. Atención primaria por parteras indígenas a mujeres en procesos de gestación, parto y posparto de las comunidades Senù los almendros, Omaga y el Pando (Bajo Cauca Antioqueño) Universidad de Antioquia. Medellín; 2013.

21. Bueno-López V, Terré-Rull C, Casellas-Caro M, Fuentelsaz-Gallego C. El impacto y la corrección de posiciones occipitoposteriores en el parto. Matronas Prof [Internet] 2015. [Consultado 11 de marzo de 2017]; 16(4):118-123. Disponible en: https://medes.com/publication/107875

22. Elizalde-Valdés VM. Calderón-Maldonado AE. García-Rillo A. Díaz-Flores M. Abruptio placentae: morbimortalidad y resultados perinatales. Medicina e Investigación 2015; 3 (2):109-115.

23. Díaz AE. Maternidad y condiciones ergonómicas de trabajo. Majadahonda: FREMAP; 2014.

24. Prado X. Embarazo y parto en la medicina tradicional del área p'urhépecha. Relaciones (Zamora) [Internet]. 1984 [Consultado 18 de febrero de 2017]; 5(20):113-120. Disponible en: http://www.colmich. edu.mx/relaciones25/files/revistas/020/XochitlPrado.pdf

25. Castro C, Cepeda C, Flórez V, Vásquez ML. Cuidado del bebé en la cultura guambiana: una mirada desde la cosmovisión de las madres. Av Enferm [Internet]. 2014 [Consultado: 09 de septiembre de 2017]; 32(1):114-123. Disponible en: https://doi.org/10.15446/av.enferm.v32n1.46069

26. Fernández N. Mitos en el embarazo: realidad científica [monografía de pregrado]. Valladolid: Facultad de Enfermería, Universidad de Valladolid; 2016.

27. Comisión Económica para América Latina y el Caribe (CEPAL). Salud materno-infantil de pueblos indígenas y afrodescendientes de América Latina: aportes para una relectura desde el derecho a la integridad cultural. Naciones Unidas, octubre de 2010. Naciones Unidas, Santiago de Chile

28. Carballo RB. Ejercicio físico durante el embarazo: programas de actividad física en gestantes. Medellín: Universidad de Antioquia; 2007.

29. Ramos CP. Prácticas culturales de cuidado de gestantes indígenas que viven en el Resguardo Zenú ubicado en la Sabana de Córdoba [tesis de maestría]. Bogotá: Convenio Universidad de Cartagena, Universidad Nacional de Colombia; 2011.

30. Mazzoldi M. Simbolismo del ritual de paso femenino entre los Wayúu de la alta Guajira. Maguaré [Internet]. 2004 [Consultado: 09 de sep. de 2017]; (18):241-268. Disponible en: https://revistas.unal. edu.co/index.php/maguare/article/viewFile/10946/11567

31. Juárez ES, Rojas JA. Implicaciones culturales en el embarazo, parto y post parto q'eqchi'. Alta Verapaz: Instituto de Investigación del Centro Universitario del Norte Cunor, Universidad de San Carlos de Guatemala; 2012. 